專題研究

\title{
專利申請補正之 性質與效果
}

\section{王服清“、張耕毓”}

\section{壹、問題之提出}

中央法規標準法第16條：「法規對其他法規所規定之同一事項而為特別之規定 者, 應優先適用之。其他法規修正後, 仍應優先適用。」行政程序法第3條第 1 項 : 「行政機關為行政行為時, 除法律另有規定外, 應依本法規定為之。」行政程序法 第34條:「行政程序之開始, 由行政機關依職權定之。但依本法或其他法規之規定 有開始行政程序之義務, 或當事人已依法規之規定提出申請者, 不在此限。」及行 政程序法第35條前段：「當事人依法向行政機關提出申請者, 除法規另有規定外, 得以書面或言詞為之。」鑑於上述規定, 專利法與行政程序法之關係十分緊密, 即 發生行政程序法於專利行政程序關係如何適用之問題。

依專利法第25條第1項及第2項分別規定如下：「申請發明專利, 由專利申請權 人備具申請書、說明書、申請專利範圍、摘要及必要之圖式, 向專利專責機關申請 之。」、「申請發明專利, 以申請書、說明書、申請專利範圍及必要之圖式齊備之 日為申請日。」故專利申請權人程序上應「主動申請」此為行政程序法第34條但書

DOI $: 10.53106 / 221845622022010048005$

收稿日：2021年8月2日

* 第一作者, 雲林科技大學科技法律研究所教授, 德國慕尼黑大學法學博士。

** 通訊作者, 雲林科技大學科技法律研究所碩士生。

專利師 | 第四十八期 | 2022年1月

Taiwan Patent Attorneys Journal 


\section{6 \\ 專题研究}

所規定的「當事人已依法規之規定提出申請者」、方式上應 $「$ 具備 5 種書面」此爲 行政程序法第35條前段所規定的「除法規另有規定外」並且「文件齊備」向專利機 關提出申請, 始爲成立專利案之申請日。

若專利申請法定文件有未齊備而產生全部或部分缺漏之情事, 專利專責機關將 以實際補齊文件之日爲申請日。若如此情事之發生, 申請日勢必延後, 申請人因此 可能遭致其他失權效果之不利益。此外, 以實際補齊文件之日作爲申請日, 該基準 日之認定也敒關是否符合專利要件或先申請原則等, 重大影䠹專利申請人之權益。 同樣地, 以外文本提出申請者亦有此問題。據此, 所衍生出來的議題有: 專利專責 機關所要求的補齊文件、專利法所規定的「齊備文件」之性質、是否有適用行政程 序法第114條「補正」之規定等問題，其虐清就顯得十分重要。

本文以「專利補正」爲核心，探討蒐集專利法與行政程序法中有關「補正」的 學說、實務判決、相關函釋等見解, 分析與回應專利補正之相關問題。

\section{蕒、補正作䉆專利申請時之成立要件}

\section{一、概 念}

專利法在程序上作爲行政程序法之特別法，因爲對於規範標的之「同一事項」 皆有規定, 且規範較行政程序法具體, 所以自應優先適用專利法的程序規定。在專 利申請行政程序上，依專利法第25條第1項及第2項分別規定程序上應主動「向專利 專責機關申請」以及方式上應 $「$ 具備 5 種書面」並且「文件齊備」時, 始爲成立專 利案之申請日。就此而言, 上述主動申請、要式以及齊備之要求係爲行政程序法之 特別規定, 符合行政程序法第34條但書規定：「當事人已依法規之規定提出申請 者」之主動申請以及行政程序法第35條前段：「除法規另有規定外」之書面要式 性。

若申請人申請專利時, 法定文件不齊備, 專利專責機關則將要求申請人「補 正」之。如此之補正, 專利法及行政程序法之條文規定分別見於專利法第 17 條第 1 項與行政程序法第114條。

至於專利法所規範之「補正」僅是對專利申請案文件有缺漏之「要式補件」，

專利師｜第四十八期 | 2022年1月

Taiwan Patent Attorneys Journal 
與行政程序法第114條所規範的「補正」之對象、治癒效果有所不同, 蓋該條所補 正的對象爲已經作成行政處分中所具有之「瑕疵」。而該行政處分的違法瑕疵存在 於程序之中, 對於已作成且生效之行政處分可以因嗣後補正而得到瑕疵治癒, 評價 上係對行政處分的程序上欠缺合法要件之嗣後治癒。反之, 申請人所提出的專利申 請, 在佮未受到專利准駁處分之前, 依據專利法第 17 條之「補正」充其量只是在程 序上之「補齊」文件而已。

\section{二、範 圍}

在收受專利申請程序中, 僅能審查專利法第 25 條第 1 項之相關法定文件, 以及 專利法施行細則第 16 條至第 23 條之發明專利申請書、說明書、申請專利範圍、摘要 及必要之圖式文件; 專利法施行細則第45條之新型專利準用發明專利文件, 以及專 利法施行細則第49條至第54條之設計專利申請書、說明書及圖式文件。本文認爲專 利申請時, 專利專責機關對於其法定文件之審查, 僅能作文件 $「$ 有」或 $「$ 無」齊備 的判斷。若齊備申請法定文件, 即應成立專利申請日, 以避免逾越收受專利申請 時, 僅應審查法定文件齊備之界限。若專利申請文件有缺漏以及與專利法所要求的 文件不齊備時, 專利申請人仍有補齊文件之機會。

\section{三、文件齊備}

專利專責機關於收受專利申請後, 若有法定文件不齊備之情形, 將指定期間命 專利申請人補齊文件, 專利申請人會準備相關資料使缺漏之文件齊備, 此乃專利 $\ulcorner$ 補正」, 亦爲「補件」的程序。專利專責機關僅能對補齊後之文件作審查, 判斷 法定文件有無齊備。專利專責機關命專利申請人補齊文件的內容爲專利法第25條第 1 項、專利法施行細則第16條至第24條所規定的文件應記載項目及格式, 而新型與 設計專利申請之處理方式, 亦同。然一旦申請文件之審查程序與形式專利要件及實 體專利要件之審查程序失去界限時, 將使專利專責機關有很大的判斷或認定之空 間, 而與實務界 ${ }^{1}$ 之預期產生落差, 將損害申請人之時間利益。

\footnotetext{
1 智慧財產法院102年度行專訴字第129號判決：「參諸專利法與其施行細則等規範, 明文設計
} 専利申請時應提出申請書、說明書及圖式等文件, 此為法定必備文件, 以全部文件齊備日或 


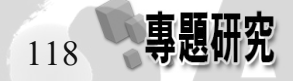

\section{四、實務案例}

最高行政法院認爲, 專利法第25條第 1 項對於物之發明, 應繳交「必要之圖 式」, 始能符合法定文件。專利申請人經補齊文件後, 僅能以補齊缺漏圖式之日爲 其申請日 ${ }^{2}$ 。然其缺漏之部分是否爲 $「$ 必要」之圖式而影䠹實質技術內容之揭露, 應 留待實質審查判斷 ${ }^{3}$ 。本文贊同最高行政法院上述之見解, 一旦專利申請時, 專利專 責機關即進行法定文件事項的實質審查, 不合乎且逾越法定文件所須受理文件的範 圍界限。

\section{五、小 結}

專利專責機關審查人員收受專利申請時, 僅得針對法定文件作審查, 檢視專利 申請文件是否有「缺漏」, 以使專利申請人能有補齊文件之機會, 補齊文件之日作 爲申請日。

智財局在收受專利申請法定文件時之審查與形式專利要件之審查, 相互混洧, 因爲兩個審查階段僅有一線之隔。申請時法定文件不齊備, 唯將欠缺之文件補齊, 始能成立申請日; 而形式專利要件審查則是對已成立申請日之專利申請案進行說明 書、申請專利範圍、圖式等揭露之專利要件審查, 其所產生之效果爲核准或駁回專 利申請案。故不得在收受申請時, 藉由指定期間命專利申請人補齊文件之機會, 制

補正日, 作為設計專利申請日, 而主張優先權者, 符合法定期間要件, 始得以優先權日為申 請日。準此, 足認被告就設計専利之申請法定必備文件, 並無裁量權, 自無有多種同樣能達 成目的之方法時, 應選擇對人民權益損害最少者之可言, 故法定必備文件不備時, 自應核駁 其申請, 並無數種有可能之法律效果之選項, 基於專利審查之行政目的, 另為其他行政行 為」。另参照最高行政法院104年度判字第183號判決、智慧財產法院102年行專訴字第100號 判決。

2 最高行政法院91年度判字第424號判決：「再審原告於八十七年六月二十三日補足圖示, 依 專利法第二十二條第一項及第二十三條前段之規定, 自應以補送相關圖示之日作為本案之申 請日。……再審原告固又訴稱: 說明書中『共同界面』及『隔離機構』在說明書中已明白揭 示, 自無需圖示進一步說明, 即圖示並非必要, 嗣因審查要求補足圖示, 但申請日為八十六 年三月十二日, 仍應以該日為準云云。」另参照最高行政法院90年判字第680號判決。

32016 年版專利審查基準第一篇第五章1-5-4頁：「申請人收到申請案之圖式有全部或部分缺 漏之通知後, 如申復無須補正或補正後又撤回全部補正之內容者, 其原申請文件之缺漏是否 影響實質技術內容之揭露而有不予專利之情事，將於實體審查時審認。」

\section{專利師｜第四十八期 | 2022年1月}


斷是否符合專利之要件, 即已進入 $「$ 修正」之實質範圍, 如此已非僅是檢視法定文 件齊備與否的申請階段所應進行的審查階段工作, 卻實際造成延後專利申請日之後 果。若非採如此之見解, 否則將與實務上時常所提及的「非可由專利專責機關決定 其法定要件」之見解, 產生矛盾。故專利專責機關審查人員應當謹守專利申請審查 程序以及專利要件審查程序之間的界限, 以達專利不同階段審查程序與其效果之明 確性。

\section{參、專利法與行政程序法「補正」之二者關係}

\section{一、詞語相同}

專利法所稱之「補正」程序, 係指使缺漏法件文件「齊備」的程序, 與行政程 序法所稱之「補正」程序, 二者雖然詞語相同但性質截然不同。行政程序法第 114 條之補正, 係針對「已作成」的「行政處分」之瑕疵, 有治癒之機會。行政程序法 第 114 條與專利法所稱之「補正」不同：專利法第17條及第 25 條應僅是對於程序上 文件缺漏所作之「補件」。況且補件係實體專利授予決定前的一種程序行為, 尚未 生起有任何的專利實體權利。若申請人主張謂, 專利專責機關要求於指定期間內補 件, 造成成立申請日遭到延後, 導致其權益受到損害, 其主張並無正當理由。

\section{二、對象不同}

專利法之補正對象為「缺」或「漏」法定文件之專利申請文件，係專利法第 25 條規定要件上之文件缺或漏, 亦即專利申請法定文件不齊備所作之補正 ${ }^{4}$ 。因此專利 法為規範專利申請業務上之補正 ${ }^{5}$ 。而行政程序法係針對有瑕疵之行政處分, 因作成

4 本文以為專利法及專利法施行細則所稱之「補正」, 係為補齊專利申請法定文件, 用語上應 稱為「補件」為宜。與行政程序法第114條對行政處分之「補正」仍有區別。

5 專利法第17條第1項：「申請人為有關專利之申請及其他程序, 遲誤法定或指定之期間者, 除本法另有規定外, 應不受理。但遲誤指定期間在處分前補正者, 仍應受理。」若専利申請 法定文件不齊備, 則審查官將指定期間要求申請人「補正」。依條文但書文義解釋, 専利申 請指定期間內之「補正」係處分前之行為。 


\section{0

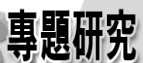

時欠缺合法要件, 爲維持其實質存續力, 可藉由補正程序或方式以治癒該處分之合 法性瑕疵 ${ }^{6}$ 。而行政處分（實體決定）有程序或方式瑕疵之補正須以該處分具有實質 存續力爲前提，因此無效之行政處分無有實質存續力，自無補正之可能 ${ }^{7}$ 。

\section{三、時機不同}

專利法之補正應先經審查官檢視專利申請法定文件後, 始得進入形式、實體專 利要件審查所爲之先行審視。若專利申請法定文件不齊備, 則應主動通知申請人補 齊法定文件 ${ }^{8}$ 。故專利法之補正係爲專利申請案成立前或准駁決定前之行爲, 即 $「$ 申 請案成立前」或「處分決定前」之補齊專利申請法定文件 ${ }^{9}$ 。相對之, 行政程序法之 補正係已作成行政處分後之嗣後補正行爲, 原則上由原處分機關職權自行爲之, 且 補正行爲本身並非行政處分, 其屬於行政處分之補充, 應視爲原行政處分之一部 分 $^{10}$ 。故行政程序法之補正爲行政處分作成後之補充行爲，即「行政處分作成後」 對程序或方式上之嗣後補正 ${ }^{11}$ 。兩者之時機差異性在於專利審查官所要求之專利申

6 洪家殷, 行政處分之撤銷及廢止、補正及轉換, 月旦法學教室, 2006年11月, 49期, 38 頁以 下。

7 吴庚、盛子龍, 行政法之理論與實用, 2020年, 385頁。

8 智慧財產法院104年度行專訴字第26號判決:「由此可證, 被告於100年8月5日收受原告之系 爭申請案後, 經程序審查即發現原告提出之文件有缺漏, 即缺少「主要元件符號說明」、圖 數與圖式不符及缺少圖一至圖三之說明等, 而於100年8月26日函請原告補正, 且被告所要求 補正內容, 並非屬形式上與修正前専利法第15條第1項 (現行専利法第17條第1項) 發明應敘 明事項、順序及方式之不符情形, 並特別註明逾限未補正將依専利法第 17 條第 1 項規定不受 理, 則可認被告對該缺漏部分認與實質技術内容有關, 並不符合専利法明確且充分揭露之原 則須由原告補正, 原告對此並未申復, 因之, 依當時之専利法施行細則第21條規定或現行專 利法施行細則第24條第1項規定, 均應以補正日為申請日。是原告主張應以 100 年9月2日為系 爭申請案之申請日期, 於法並無不合。」

9 専利法第 17 條第1項。

10 李惠宗, 行政法要義, 2020年, 396頁。

11 法務部法律字第10103109530號函（民國102年1月9日）：「按行政程序法（以下稱本法）第 114第1項第1款規定：『違反程序或方式規定之行政處分, 除依第111條規定而無效者外, 因 下列情形而補正：一、須經申請始得作成之行政處分, 當事人已於事後提出者。』上開瑕疪 處分之補正, 僅限於可補正之程序瑕疪, 實體上之瑕疪原則上不在補正之列」。另參見法務 部法律字第10603508250號函（民國106年6月16日）、法務部法律字第10703512840號函（民

專利師｜第四十八期｜2022年1月

Taiwan Patent Attorneys Journal 
請補正行爲, 向未進入專利形式或實質要件的審查階段, 更未作成專利准駁處分。 反之, 行政程序法之補正卻是對已作成的行政處分之事後補充行爲。

\section{四、效果不同}

專利法第25條第2項明文規定之文件齊備日作爲專利申請之申請日。專利申請 必須齊備申請書、說明書、申請專利範圍、摘要及圖式以符合專利法第 25 條第 1 項 法定文件之規定。之後, 實體專利要件審查程序也依專利成立申請日, 作爲是否符 合專利要件之判斷日 ${ }^{12}$ 。若申請時法定文件有缺漏時, 則應補齊文件, 以補齊日作 爲成立申請日。

若作成行政處分業已生實質確定力, 其有瑕疪之部分向屬輕微, 未達處分無效 之程度 ${ }^{13}$, 可藉由行政程序法之補正治癒有瑕疵但已經生效之行政處分 ${ }^{14}$, 免於被 撤銷。

\section{五、法源不同}

專利法施行細第24條、第40條、第55條僅給予說明書或圖式已見於主張優先權 之先申請案或以外文本申請之文件爲準, 以原提出申請之日爲申請日的規範, 卻沒 有給予無主張優先權之國內專利申請案缺漏說明書或圖式以原提出申請日作爲申請

國107年8月30日）。

智慧財產法院102年度行專訴字第129號判決：「専利實體審查之要件：専利程序審查有別於 尃利實體要件之審查, 專利程序審查檢視各種申請文件, 是否合於專利法及專利法施行細則 之規定, 就新申請案以觀, 經程序審查, 認定文件齊備, 始取得申請日。實體審查程序, 依 據程序審查時所確認之申請日, 繼而審查其專利要件, 並認定後續之補正或修正, 有無逾其 取得申請日之說明書或圖式所揭露之範圍。不論是中文本或外文本提出申請之設計専利申請 案, 說明書及圖式均為法定取得申請日之要件, 而說明書至少有設計名稱, 在程序審查時, 自以申請人補正載有設計名稱之說明書之日, 作為申請日, 始得進行實體審查。」 吴庚、盛子龍, 註7書, 385 頁。

14 翁岳生, 行政法 (上) ——行政處分 (許宗力執筆) , 2020 年, 670 頁。另参見吴志光, 行 政處分程序瑕疪之法律效果, 月旦法學教室, 2003年2月, 4期, 26 頁; 蔡茂寅, 行政處分之 瑕疪及其效果, 月旦法學教室, 2011年8月, 106期, 8 頁以下。 


\section{2 專题研究}

日之相關規定。且專利法並無明文規定，該以何日作爲申請日的認定標準 ${ }^{15}$ 。

本文認爲, 除非符合專利法施行細則主張優先權之先申請案或以外文本申請之 例外情形者, 否則無法以原提出申請日作爲申請日。亦即專利專責機關命申請人於 指定期間內補齊文件，以齊備文件日作爲申請日。專利申請以齊備文件作爲申請日 相較於原提出申請日勢必遭到延後, 申請人主觀感受上認爲受有損害, 然法律已明 文規定齊備法定文件才能成立申請日，係無法以爭執 $「$ 以原提出申請日作爲申請 日」作爲法定理由。

行政程序法第114條係對已作成之行政處分給予瑕疪治癒之補正機會。相較 之, 收受專利申請之審查程序應在未作成行政處分之前, 依據專利法第25條第2 項 規定的要式文件須齊備之, 否則不成立申請日。專利申請審查程序上的「補正」行 爲, 無法根據行政程序法第 114 條「補正治癒」之規定，以嗣後補齊文件來「治 癒」申請日, 僅能待補齊法定文件時, 以成立申請日。故專利申請的「補正」不適 用行政程序法第114條之「補正」，無有爭執之餘地。

\section{六、目的不同}

專利法施行細則的立法理由提及到參考專利法公約第5條第6項規定所設成立申 請日之例外規定, 僅有符合補正說明書、圖式 $「$ 見於」優先權之申請案或外文本, 始有適用申請人以原提出申請之日爲申請成立日之餘地 ${ }^{16}$ 。而行政程序法第114條之 補正係立法者所訂定處分無效之例外規定 ${ }^{17}$, 其目的爲維持法秩序安定性, 並促進 行政效率 ${ }^{18}$ 。

15 智慧財產法院104年度行專訴字第26號判決：「然發明說明中之圖式簡單說明未說明圖式及 主要元件符號, 於程序審查階段通知補正, 雖未明文規定以補正日為申請日, 但依當時之甫 利法施行細則第21條『說明書有部分缺頁或圖式或圖面有部分缺漏之情事者, 以補正之日為 申請日。』之規定本文，應仍以申請人補正之日為申請日。」

16 専利法施行細則第24條、第40條、第55條。

17 参見法務部法律字第10103109530號函（民國102年1月9日）、法務部法律字第10603508250 號函（民國106年6月16日）、法務部法律字第10703512840號函（民國107年8月30日）。

18 翁岳生, 註14書, 678 頁。另参見李惠宗, 註10書, 396頁。

專利師｜第四十八期 | 2022年1月

Taiwan Patent Attorneys Journal 


\section{七、小 結}

專利法及專利法施行細則之「補正」係對專利申請有缺漏法定文件所爲之規 定, 其與行政程序法第114條之「補正」係對有瑕疵但已生效後之行政處分作出 $「$ 瑕疵」治癒，並不相同，且其二者規定非針對規範標的之同一事項。

況且專利申請程序之目的係爲達成核准、裁決專利申請案之行爲或措施 ${ }^{19}$, 並 非「已作成」的行政處分, 故專利法之「補齊」文件係針對行政處分前的行爲。因 此, 專利法與行政程序法二者所稱之「補正」, 不管其對象、治癒效果等, 差異甚 大, 截然不同。

本文以爲, 「欠缺文件」即屬自始沒有齊備法定文件, 無法成立申請日。「漏 掉文件」係提出申請時雖已經齊備法定文件, 惟文件內容必要應記載上有欠缺, 使 法定文件不完整而言。兩者皆屬爲法定文件不齊備之態樣, 須待補齊文件完成後, 始確定申請日, 才符合專利法第25條第2項規定之申請成立要件, 不生行政程序法 第114條第1項規定的補正與否之問題。因爲專利專責機關每年處理大量專利申請 案, 避免申請人有投機想法而藉由「補件」制度, 以搶先成立申請日, 導致降低專 利行政審查效能, 故立法者有意規定, 授權交由機關認定法定文件是否「齊備」作 爲成立申請日之標準。

\section{肆、專利補正之缺漏}

\section{一、缺漏程度}

\section{(一) 量的區別}

提交發明或新型專利申請時, 須齊備申請書、說明書、申請專利範圍及圖式之 法定文件, 方能成立申請日 ${ }^{20}$ 。設計專利申請則應齊備申請書、說明書及圖式之法 定文件, 進而成立申請日 ${ }^{21}$ 。且應符合專利法施行細則第 16 條至第 23 條發明專利申

\footnotetext{
19 吴志光, 不服行政機關程序行為之救濟, 法學講座, 2002年2月, 2期, 91頁。

20 専利法第25條第2項、第106條第2項。

21 專利法第 125 條第2項。
} 


\section{4 專题研究}

請應記載事項、專利法施行細則第45條新型專利申請準用發明專利申請應記載事 項、專利法施行細則第49條至第54條設計專利申請說明書及圖式應記載事項。

專利法第25條第3 項：「說明書、申請專利範圍及必要之圖式未於申請時提出 中文本, 而以外文本提出, 且於專利專責機關指定期間內補正中文本者, 以外文本 提出之日爲申請日。」我國明訂先提出外文本申請之制度, 方便國外最新技術資訊 引進國內, 活絡國內技術。故以外文本提交發明及新型專利申請, 仍需符合說明 書、請求項及圖式等相關規定 ${ }^{22}$, 以成立外文本之申請日。而設計專利申請則應具 備圖式並載明設計名稱 ${ }^{23}$ 。後來補正之中文本亦得援用外文本作爲申請日。

審查機關在收受專利申請時, 若申請人在法定文件上, 欠缺任何一個要件, 即 無法成立申請日。決定申請日對公眾權益影響重大, 因爲若欠缺法定文件時仍給予 申請日, 對於其他齊備文件提出申請之申請人不公平。再者, 已經欠缺法定文件, 即當然不成立申請日。經由專利專責機關指定期間內補齊文件, 即應以補齊文件之 日爲其申請日，並無爭執之空間。此乃法定文件上「缺」的概念。

\section{(二) 質的區別}

專利法第25條第1項及第2項所規定的發明專利申請須「必要」之圖式。發明 專利包括物與方法發明, 其技術內容並非均有圖式, 只有「必要時」才須檢附圖 式 ${ }^{24}$ 。此乃決定申請日有關法定文件的「質性」規範。

因爲提交專利申請時，對於專利法之法定文件已經齊備，因已符合成立申請日 之要求, 即應成立申請日。所以在文件之內容及事項上有記載不完整時, 應屬於修 正之範圍。若以形式專利要件或實體專利要件審查階段之事項標準, 要求申請人於 指定期間內即應補齊文件, 即不符合成立申請日僅需法定文件之規定。舉例來說, 申請人申請時已繳交圖式, 然圖式不足以揭露創作內容。此種情形應屬於形式專利

22 專利以外文本申請辦法第4條第1項：「發明專利以外文本申請者, 應備具說明書、至少一項 之請求項及必要圖式。」第4條第2項：「新型專利以外文本申請者, 應備具說明書、至少一 項之請求項及圖式。」

專利以外文本申請辦法第4條第3項：「設計専利以外文本申請者, 應備具圖式, 並載明其設 計名稱。」

24 經濟部智慧財產局編印, 専利法逐條釋義, 2021年, 79頁。

專利師 | 第四十八期 | 2022年1月

Taiwan Patent Attorneys Journal 

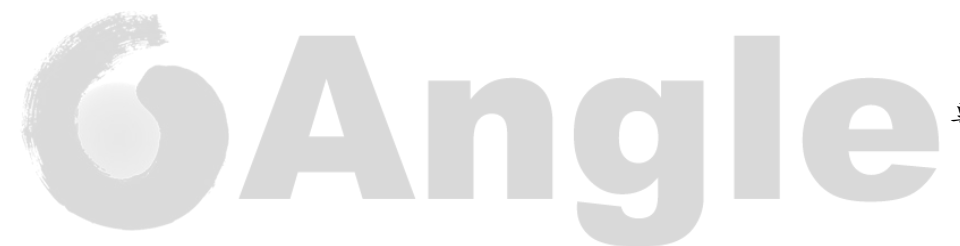

專利申請補正之性質與效果 125

要件或實體專利要件之審查階段, 應以「修正」程序來修改或補充創作內容。若以 $\ulcorner$ 修正」程序做出補正法定文件的要求, 實質上已牽涉到法定文件之內容, 將造成 法定文件的「補件」與其內容「修正」之程序, 混爲一談, 易造成延後成立申請日 之不利結果。另一方面, 若是說明書上所應記載之圖式有 1 至 10 圖, 而繳交之文件 上僅有 1 至 8 圖。縱使文件漏掉的部分向屬「輕微」, 仍應認爲不齊備專利法第 25 條、第106條、第125條之法定文件，此乃法定文件上「漏」的概念。無論「欠缺」 或「漏掉」法定文件, 皆屬於法定文件的不齊備。故經由專利專責機關指定期間內 補正文件, 以補正文件之日爲成立申請日。

\section{二、法定文件之漏未補正與仍有瑕疵}

最高行政法院108年度判字第309號判決與智慧財產法院 105 年度行專訴字第47 號判決針對專利申請法定文件不齊備, 提出「補正文件仍有瑕疵」 25 、「漏未補 正」 ${ }^{26}$ 之兩種補正態樣。補正文件仍有瑕疵之概念係指申請人提出專利申請法定文 件上有缺漏, 對缺漏文件所作的補正, 經過專利專責機關審查人員審查後仍有瑕 疵, 應在指定期間內補齊缺漏文件。而漏未補正之概念係指就通知應補正之申請文 件, 未針對專利專責機關審查人員所要求之申請文件補正。此牽涉到行政機關長年 專利實務之作法，涉及有無違反平等原則及行政自我拘束原則之問題 ${ }^{27}$ 。

25 智慧財產法院 105 年度行専訴字第47號判決：「然所謂『補正文件仍有瑕疪』，與『漏未補 正』乃屬不同之概念, 就此被告亦已於本院所命書狀先行程序中詳加說明：『補正文件仍有 瑕疪』係指申請人原所補正之申請文件, 經核有瑕疵, 並非就尚未補齊之申請文件再限期通 知補正。例如: 申請人所補正之委任書上委任人為未蓋印章或蓋錯印章, 即限期通知申請人 重新補正蓋有正確申請人印章的委任書（被告行政訴訟補充答辯書第2頁, 本院卷第137頁背 面）。兩者既有所不同, 即無從自我拘束, 亦無從請求相同處理對待。」

智慧財產法院105年度行専訴字第47號判決：「原告可能進一步認為：基於行政服務之理 念, 既然補正文件有瑕疪之情形, 可以通知重新補正, 何以漏未補正就不能也比照通知再補 正? 就此本院認為: 補正文件有瑕疵, 畢竟已有補正, 但漏未補正則是根本未補正, 倘寬認 後者亦必須通知再補正, 等同原先指定補正期間, 毫無意義, 申請人均可無視於原先之補正 通知, 等待第二次通知再行補正。」

27 智慧財產法院105年度行專訴字第47號判決：「所謂信賴保護原則, 依行政程序法第117條規 定, 應以違法行政處分作為信賴對象; 雖然司法院大法官釋字第525號解釋進一步將信賴對 象擴及至抽象之法規, 但行政實務之作為或不作為可否亦成為信賴對象, 似未有司法上之權 


\section{6 專题研究}

本文認爲, 區別上述兩種補正態樣並無實益。兩種態樣皆爲作成准駁處分之 前, 應當補齊之文件, 故探討專利專責機關有無發出「補正通知」並非「補正」之 重點。無論專利專責機關有無發出補正通知，因申請人本身本可就對法定文件作

$\ulcorner$ 補正」, 使缺漏文件之專利申請盡速補齊文件, 進而早日確定專利申請之申請 日。

據此, 補齊文件之前提, 並非㽎酌於補正是否應作出補正通知, 或專利專責機 關作通知 $\left\ulcorner\right.$ 補正」時, 會不會拖累行政效能 ${ }^{28}$ 。反而是, 申請人與專利專責機關應 協力合法地進入專利審查程序。因「欠缺」或「漏掉」法定文件，不符法定之成立 要件, 爭執以何日爲申請日已無實益, 故申請人應盡早齊備法定文件, 以成立申請 日，方爲實益。

以下討論「補正態樣」, 針對不同「缺漏」法定要件之補齊文件態樣, 予以 分析。

\section{三、態 樣}

\section{(一) 發明專利申請之文件缺漏}

智慧財產法院104年度行專訴字第26號判決認爲，申請人提交申請時，說明書 欠缺符號說明，並且就圖式及圖式簡單說明處，有缺漏而無法使說明書明確且充分 揭露。前者違反專利法施行細則第17條第1項第7款欠缺說明書應記載事項，屬於申 請時法定文件不齊備，產生不受理之效果。後者違反專利法第26條第1項屬於說明 書記載不完整。對於符號說明屬於「欠缺」法定文件，其應記載要件及格式不符合

威解釋。究其原因在於：信賴保護又可分為存續保護（行政程序法第117條但書參照）與補 償保護（同法第120條第參照）, 非必為存續保護, 是其保護強度反而低於要求相同事物相 同處理之平等原則或行政自我拘束原則。因此, 對於一項行之有年之行政實務, 人民基於平 等原則、行政自我拘束原則, 人民本可請求行政機關按照實務作法而作為, 根本無待再行主 張信賴保護原則，故而討論行政實務之信賴保護似乎缺乏其真正實益。」 的申請人, 但就整體專利申請制度而言, 將為此增加難以估算之行政成本, 拖累專利申請之 審查效能, 進而影響其他遵期補正之勤勉申請人受到更快審查的合法權益。從而, 『漏未補 正』即不應比照『補正文件』有瑕疵辦理。」

專利師｜第四十八期 | 2022年1月 
規定, 無法成立申請日。後者爲說明書記載內容不完整, 屬於「修正」之範圍。吾 人綜合判斷, 前者已無法成立申請日, 就沒有後面「修正」的問題, 判決將成立申 請日延後之作法正確。

再者, 說明書及圖式之功能係得以明確、充分揭露創作技術內容, 使公眺或該 發明所屬技術領域中具有通常知識之人能得以理解, 以揭露必要之技術訊息爲目 的。說明書撰寫明確要件屬於形式專利要件審查之範疇, 不應當於申請時法定文件 即探究說明書揭露有無明確且充分揭露, 更何況審查說明書之實質技術內容 ${ }^{29}$, 即 進入針對申請法定文件審查階段先前判斷。申請時應當只是對於法定文件上齊備與 否作檢視。因此, 專利專責機關審查申請法定文件時, 應爲依法定文件不齊備爲 由, 要求申請人補件。

\section{(二) 新型專利申請之文件缺漏}

臺北高等行政法院96年度訴字第1162號判決認爲, 專利申請欠缺申請專利範圍 及新型說明, 違反專利法第106條第1項專利申請之法定文件及專利法施行細則第45 條新型準用發明說明書應記載事項。判決指出「說明書顯然不完整」，其「欠缺」 申請專利範圍及新型說明, 應以補齊文件之日爲其申請日。而判決引用的法條爲專 利法第26條第 1 項說明書揭露要件 ${ }^{30}$, 其應屬於形式專利要件審查階段的範圍。一者 應以專利法第106條第1項及第2項新型專利申請法定文件之規定爲依據。二來判決 將收受專利申請審查程序與形式專利要件審查程序審查範圍作連結, 本文持否定見 解。同前所述, 應以不齊備法定文件爲由, 要求申請人於指定期間補齊文件, 以便 儘早確定申請日。

臺北高等行政法院94年度訴字第3842號判決認爲, 專利申請之圖式有漏掉, 違 反專利法第106條新型專利申請法定文件之規定。專利申請人對於本身漏掉之圖式

29 智慧財產法院104年度行專訴字第26號判決。

30 臺北高等行政法院96年度訴字第1162號判決：「查原告等於95年5月26日向被告所彪送之本 案『新型專利說明書』除記載有新型名稱、申請人、創作人等基本資料外, 在『中文新型摘 要』闌, 列有名稱、主旨及說明, 在『指定代表圖』及『圖式』欄則列有本案兩個代表圖及 元件符號簡單說明, 此外別無其他内容, 與専利法第26條第 1 項所規定専利說明書要件相 較, 尚缺少『新型說明』與『申請専利範圍』雨部分, 其說明書顯然不完整。」

專利師 | 第四十八期 | 2022年1月 Taiwan Patent Attorneys Journal 


\section{8

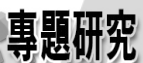

並無爭執 ${ }^{31}$ 。然其討論的重點在於漏掉之圖式是否必要之圖式 ${ }^{32}$ 。本文認爲, 若係 屬說明書所應記載之圖式, 即爲專利法所規定之「必要」之圖式。因爲要進入審查 之申請案內容前, 必須具備明確應記載之法定文件。因此, 只要是申請人欲主張之 技術內容, 且說明書內容上有應記載的圖式, 即爲應繳交的法定文件。故專利申請 確定申請日後, 這些法定文件將成爲形式專利要件及實體專利要件程序要審查的內 容。綜上所述, 說明書中應記載第 1 圖至第 9 圖, 申請人雖然已繳交第 1 圖至第7圖, 然而第 8 圖及第 9 圖屬於「漏掉」的法定文件, 仍應將「漏掉」的圖式, 補齊之, 始 成立申請日。

\section{(三) 發明專利申請中文本之文件缺漏}

臺北高等行政法院 89 年度訴字第3 67 號判決認爲, 申請人於申請時, 以外文本 提交申請, 事後補齊中文本之法定文件。專利專責機關多次通知「補正」, 其申請 日遭到延後, 而以最後中文本齊備之日爲其申請日 ${ }^{33}$ 。如此增加專利申請人的不利 益, 在固定的資源下, 無法產生最大之專利行政效能, 使申請人對專利專責機關失 去信賴。專利專責機關在任何審查階段, 若不符合申請時法定文件審查之規定, 將 得到何種不利益之效果, 應使每一個審查階段、要件、範圍及標準皆能明確。使機 關及申請人都能預見, 發揮最大的審查效能。而非消耗彼此之時間、精力, 應當增

31 臺北高等行政法院94年度訴字第3842號判決：「本件原告係於93年10月14日檢送新型專利申 請書, 該申請書之說明書第 11 頁之『圖式簡單說明』中載有第 1 圖至第 9 圖之相關說明, 惟其 後所附之圖式僅有第1圖至第7圖, 缺漏第 8 圖及第 9 圖之事實, 有新型専利申請書及說明書各 一份在卷足憑, 且為原告所不爭執, 洵堪認定。」

臺北高等行政法院94年度訴字第3842號判決：「至原告主張其所補送之第8圖及第9圖為先前 技術說明之相關圖面（示）, 非専利法第108條準用第25條所稱之『必要圖式』乙節; 惟查 若無先前技術說明之相關圖面（示）, 則無從就系爭案與先前技術加以比較, 自難以判断系 爭案較諸先前技術更具新穎性及進步性, 故先前技術說明之相關圖面 (示) 之齊備與否, 在 系爭案審查上有其重要性, 該等圖面（示）自屬專利法第108條準用第25條第3項所規定之必 要圖式。原告上開主張, 容有誤解, 自不足採。」

33 臺北高等行政法院89年度訴字第367號判決：「查原告既於申請時以外文文件先行提出依法 應備具之說明書, 經被告多次通知補正後, 始於八十七年八月十七日提出中文說明書及中文 圖式, 故被告以本案申請日應以文件齊備之八十七年八月十七日為準, 揆諸首開規定, 並無 不合。」

專利師 | 第四十八期 | 2022年1月

Taiwan Patent Attorneys Journal 
進信賴關係, 進而促進產業發展。而依專利法第25條第4項之意旨, 逾指定期間內 補正 ${ }^{34}$ 中文本者, 其申請不予受理。但在處分前補正者, 以補正之日爲申請日, 外 文本視爲未提出。

\section{(四) 發明專利申請外文本之文件缺漏}

以外文本提出專利申請, 仍應繳交說明書、請求項及圖式等法定文件。至於應 記載事項規定在專利以外文本申請辦法第 4 條。而申請人於指定期間內補正 ${ }^{35}$ 中文本 時, 得以外文本作爲申請日 ${ }^{36}$ 。若中文本說明書或圖式有缺漏, 中文本補正之說明 書或圖式, 已出現於外文本者, 中文本亦得以外文本之文件爲其申請日 ${ }^{37}$ 。

本文認爲, 專利法施行細則第24條、第40條及第55條之規定爲針對曾主張優先 權之先申請案及以外文本提出申請者, 係屬於申請日之例外規定。

未曾在國外提出申請且成立申請日或以外文本提出申請者, 僅有法定文件項目 上可以齊備, 專利申請之申請日並未以原提出申請日作爲申請日。實務上依專利法 施行細則之規範作例外規定的解釋, 並非以直接規範補齊文件後申請日之判斷 ${ }^{38}$ 。

依據專利以外文本申請辦法第4條之規定, 發明、新型及設計之外文本仍須符 合一定格式及應記載方式, 始成立外文本申請日。其與一般專利申請成立申請日之 方式相同, 皆須符合法定文件、格式及應記載方式, 始能成立外文本之申請日。故 外文本 $\ulcorner$ 欠缺」或「漏掉」時, 仍應予以補齊文件。

最高行政法院100年度判字第945號判決：「是以申請專利之發明, 不問係以中 文本或外文本提出申請, 抑或其有無主張優先權, 其取得申請日之要件均爲申請時 應備齊申請書、說明書及必要圖式等書件, 晌申請人係以外文本先行提出申請, 如 於專利專責機關指定期間內補正中文本者, 依法應以外文本提出之日爲申請日, 其 圖式如屬該專利案之必要圖式, 而未於申請時一㢸提出者, 惟已在處分前補正者,

\footnotetext{
34 此之「補正」為條文之用語, 與本文所稱之「補正」有別。本文所提及之「補正」, 係為使 「缺漏」之法定文件「補齊」，即「補齊文件」而言。

35 同前註。 專利法第25條第3項。 専利法施行細則第24條第2項。

38 智慧財產法院104年度行專訴字第26號判決。
} 


\section{0 專题研究}

則以補正之日爲申請日，此爲原判決闡釋在案，經核並無不合。」

上述判決之見解亦強調如以外文本提出申請者, 申請書、說明書及必要圖式爲 其法定文件, 以及專利以外申請實施辦法第4條之申請專利範圍請求項。如爲設計 專利設計名稱及圖式爲其必備法定文件 ${ }^{39}$ 。收受專利申請審查階段時, 應齊備法定 文件始能成立外文本之申請日。

臺北高等行政法院97年度訴字第136號判決認爲, 專利申請人以外文本提出申 請時, 外文本欠缺圖式, 經過補齊後以補齊文件之日爲其申請日 ${ }^{40}$ 。不管一般專利 申請者或以外文本提出申請者, 其僅是申請軌道不同。然對於齊備法定要件, 成立 申請日之規範上, 法理相同。該判決之原告, 外文本「欠缺」圖式。其屬於法定文 件上之不齊備, 無法成立申請日, 應以補齊文件之日爲其申請日。

申請時法定文件若屬於專利專責機關因處理行政業務上所遇到之問題, 而造成 專利申請人成立之申請日遭到延後。亦導致可得知文件缺漏, 搶救缺漏文件之補正 日期延後, 損及申請人專利申請之申請日, 而可歸責於專利申請人 ${ }^{41}$ 。此時, 申請 日應如何認定? 本文以爲, 專利專責機關對於收受專利申請, 本就有確認及審查法 定文件齊備之職權責 ${ }^{42}$, 對於申請人有利事項應一律注意 ${ }^{43}$ 。專利行政業務之作法

39 專利以外文本申請辦法第4條第3 項。

40 臺北高等行政法院97年度訴字第136號判決：「原告於95年12月5日檢附申請書、外文說明書 一式2份及優先權證明等文件, 向被告申請發明専利, 同時主張優先權, 因外文圖式等必要 書件未齊備, 經被告以前揭95年12月20日函請原告於96年4月5日前補正所欠缺之文件。原告 雖於96年3月20日補正, 惟依首揭専利法第25條第3項及第4項規定, 仍應以外文圖式齊備之 日為本案之申請日, 故本案申請日應為96年3月20日。」

41 臺北高等行政法院97年度訴字第136號判決：「按申請書附件是否隨申請書同時附送, 為事 實認定問題, 宜就具體個案認定。本院95年5月3日95年訴字第2796號判決係針對個案所為之 事實認定, 該判決雖認依一般經驗法則, 行政機關收文單位於收受申請文件時, 其承辦人對 申請文件應具備之要件、附件之種類及數量會作形式之審查以避免爭端云云, 惟被告因收文 量龐大, 當場點收將造成申請人不便且耗時費力, 實務運作上有其困難, 因此, 並未就申請 案之附件進行逐件點收。確與一般行政收文單位作法不同, 實難因為有該判決之作成, 即比 附援引在通案上認定凡被告有收文者, 即表示文件均已檢送, 否則將失去系爭專利為事實認 定之本質。」

42 行政程序法第9條：「行政機關就該管行政程序, 應於當事人有利及不利之情形, 一律注 意。」

43 最高行政法院 100 年度判字第 945 號判決：「上訴意旨略謂：原判決對於被上訴人未依行政程

專利師｜第四十八期｜2022年1月

Taiwan Patent Attorneys Journal 

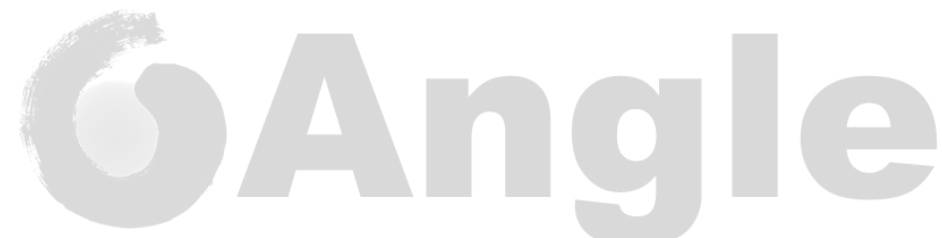

專利申請補正之性質與效果 131

固然並未違法, 然僅是適當與否之問題。對於申請人已經可以預見, 若文件不齊備 會產生不受理之結果，何況是具備專利代理資格之人。

\section{(五) 設計專利申請外文本之文件缺漏}

專利法第125條第1項：「申請設計專利, 由專利申請權人備具申請書、說明書 及圖式, 向專利專責機關申請之。」設計專利申請須具備申請書、說明書及圖式向 專利專責機關提出申請, 以其齊備之日爲申請日 ${ }^{44}$, 此爲一般設計專利申請所應準 備之法定文件。以外文本提出專利申請者, 亦須符合專利以外文本申請實施辦法第 4 條第3 項之規定, 事後再補上中文本。而外文本應記載事項, 最低限度至少應記載 設計名稱及圖式 ${ }^{45}$ 。設計專利申請明確載明設計名稱與圖式, 才能界定設計專利權 範圍及其應用之物品 ${ }^{46}$ 。

最高行政法院104年度判字第180號判決、智慧財產法院103年度行專訴字第7號 制決、智慧財產法院 102 年度行專訴字第 100 號判決、慧財產法院102年度行專訴字 第111號制決涉及設計專利申請以外文本提出者, 其欠缺外文說明書, 且所提出之 外文本圖式亦無設計名稱 ; 最高行政法院104年度制字第183號判決、智慧財產法院 102 年度行專訴字第 129 號判決涉及外文本欠缺設計名稱及說明書。以上皆屬於以外

序法第 9 條規定, 就系爭案之圖式是否隨申請書同時附送, 一律注意, 且未能排除系爭案之 圖式在其作業程序上遗失之可能性等情, 未予審酌, 遥為上訴人不利之認定, 有判決不適用 法規及適用法規不當之違法; 系爭案於申請時已附有必要圖式, 未違反專利法第 25 條第 $3 、 4$ 項規定, 而有專利法施行細則第21條之適用, 且98年7月7日之提出申請日, 應可依専利法第 27 條第1項主張國際優先權, 原判決認事用法顯有違誤云云, 係就原審所為論斷或駁斥其主 張之理由, 泛言原判決不適用法規或適用不當, 自非足採。」 専利法第 125 條第 2 項。

智慧財產法院102年度行専訴字第129號判決：「是外文本申請辦法與専利審查基準鲁编之規 定, 已考量减輕申請人準備申請文件之負擔, 而將外文本之揭露方式簡化至最低限度, 並可 兼顧專利法及專利法施行細則等相關規定。準此, 專利以外文本提出申請者, 倘在圖式已載 有設計名稱者, 得認定申請人已提出說明書及圖式, 倘申請人僅提出圖式, 而未載有設計名 稱, 自無從認定申請人已提出說明書或以外文本申請者應記載事項。」

46 最高行政法院104年度判字第180號判決：「故其所規定設計専利以外文本提出申請者應備具 圖式並載明其設計名稱之要件, 係為確認設計專利所揭露之範圍, 及維護申請人與第三人之 權益所必要, 復與専利法規定並無牴触, 原處分予以援用, 於法並無不合。」

專利師｜第四十八期 | 2022年1月 Taiwan Patent Attorneys Journal 


\section{2 專题研究}

文本提出專利申請後, 文件格式或項目上有 $\ulcorner$ 欠缺」之情況, 申請時即不齊備法定 文件，專利申請無法成立申請日，仍應以文件齊備之爲申請日。

本文認爲，不同類型的專利申請，僅是應記載方式、格式及項目上有所不同。 專利法對於 $\left\ulcorner\right.$ 補正」程序及以原提出申請日作爲申請日並未完整規範 ${ }^{47}$ 。因此, 必 須補齊「缺漏」之文件, 以便確定申請日。而補齊「欠缺」之法定文件, 其申請一 開始就無法成立申請日, 縱使補齊「欠缺」之文件, 仍無法以原提出申請日作爲申 請日，以補齊文件之日爲其申請日。若爲「漏掉」之法定文件，認定申請日之，亦 同。

以外文本提出之申請「缺漏」法定文件，又或者是在發明、新型或設計專利申 請「缺漏」法定文件, 在專利法皆定有其應繳交及應記載之事項。機關收受專利申 請時應先判斷是否齊備法定文件, 若有齊備法定文件, 則成立申請日, 即應進入形 式專利要件審查階段。若「缺漏」法定文件, 則應要求申請人於指定期間內補齊文 件。

申請人會質疑專利專責機關對收受申請法定文件的見解, 非無理由。但專利專 責機關在審查時, 以形式專利要件或實體專利要件審查之標準, 藉由審查專利申請 之法定文件時, 要求申請人「補正」, 實際上已經爲「修正」程序之範圍。

法院在審查專利「補正」程序時, 基於三權分立之原理, 僅能針對適法性作審 查, 對於專利審查決定應予以尊重。而以原提出申請日作爲申請日之法源僅見於專 利法施行細則第 24 條、第 40 條及第 55 條, 以曾主張過優先權之先申請案或以外文本 提出者, 以說明書或圖式內容爲以原提出申請日作爲申請日依據, 係爲齊備文件之 例外規定。專利專責機關及法院如此的審查並未違法, 僅是審查階段所應審查的項 目及範圍是否妥當的問題。

\section{伍、總 結}

雖然專利程序爲行政程序法之特別程序, 並無疑義, 然對於專利法及專利法施 行細則與行政程序法所規定之「補正」, 兩者卻無法成立普通法與特別法之關係,

47 智慧財產法院104年度行專訴字第26號判決。

專利師｜第四十八期｜2022年1月

Taiwan Patent Attorneys Journal 
因爲兩者之規定並非針對專利申請補齊法定文件作爲規範標的之「同一事項」。而 且其二者有關補正規定之目的、對象及效果等更是大相逕庭。故專利申請人之專利 申請無法主張行政程序法第114條之補正而得到瑕疵治癒。反而, 申請人卻是應盡 早於審查官指定期間內補齊法定文件, 以期迅速成立專利申請之申請日。因此專利 法所稱之「補正」係申請人將專利法第 25 條所規定 5 種法定文件補齊之行爲, 始能 成立專利申請之申請日。

專利專責機關嚴格地爲專利申請把關, 避免申請人投機。在其提交法定文件 時, 若务促地繳交文件, 就能迅速取得申請日, 以原提出申請日作爲申請日, 將會 濫用專利「補正」程序之機會, 造成不利影響公眾權益之疑慮。本文認爲, 專利申 請程序就像漏斗一般, 採用過濾式審查之作法, 層層審查專利申請的法定文件與要 件。程序審查一開始即要求補齊文件, 或於指定期間內, 以補齊文件之日作爲其申 請日。透過各個階段的審查標準, 逐漸淘汰不適合的專利申請, 同時亦不可將後階 段應判斷的實體專利要件, 提前到收受文件或形式專利要件審查階段作爲判斷之標 準, 應當恪守 $「$ 先程序後實體」之階段性原則 ${ }^{48}$ 。但是如果專利專責機關以形式專 利要件或實體專利要件審查之標準, 指定期間要求申請人補齊文件, 往往造成延後 申請日之時間不利益, 易使申請人質疑專利專責機關有意爲難的不良感受。專利法 的意旨係以鼓勵、保護、利用發明、新型及設計之創作, 達到促進產業發展的目 的。不應將防弊心態大於興利, 將努力研發創作之人一開始就因法定文件之不齊備 與法定要件之預設判斷, 就阻擋在受理程序之外, 或就只是爲了應付程序或文件疲 於奔命, 造成優良的創作不受理或延展申請日。專利專責機關應教示創作人符合程 序及法定要式之要求, 申請人亦應理解專利專責機關爲專利申請把關之用心, 共同 協力完成專利審查程序。

48 智慧財產法院 102 年度行專訴字第 129 號判決: 「然專利専責機關收受申請案後, 審查人員應 先進行程序審查, 倘有欠缺者, 應先命補正, 不補正者, 則馶回其申請。程序審查後, 繼而 就申請案進行實體審查。此稱先程序後實體之原則, 所有設計專利申請案, 合於程序要件 者, 始得進入實體審查, 是合於程序審查乃設計專利申請案進入實體審查之前提。」

專利師 | 第四十八期 | 2022年1月 Taiwan Patent Attorneys Journal 